Alexandre Marques da Silva', Daniela Silvia de Oliveira Canuto'+, Mario Luiz Teixeira de Moraes'

\title{
GENETIC PARAMETERS IN RIPARIAN REFLORESTATION WITHOUT STRUCTURE OF PROGENIES BY MIXED MODELS (REML/BLUP)
}

Keywords:

Multivariate analysis

Genotypic divergence

Conservation

Historic:

Received 09/10/2017

Accepted 19/12/2017

Palavras chave:

Análise multivariada

Divergência genotípica

Conservação

+Correspondence: dsocanuto@gmail.com
ABSTRACT: The objective of this work is to estimate genetic parameters for silvicultural traits in riparian reforestation at 20 years of age, without progeny structure by mixed models (REML / BLUP). The present work was carried out at the Fazenda de Ensino, Pesquisa e Extensão (FEPE) of the Faculdade de Engenharia de llha Solteira, Universidade Estadual "Julio de Mesquita Filho" (FEIS/UNESP), located in the municipality of Selvíria (MS). In February and March of 1986 began the planting of the riparian reforestation in modules, existing two Modules with different numbers of species. The spacing used in the planting of the species was $2 \times 3 \mathrm{~m}$. The riparian reforestation has an area of 9.5 ha in the total sum of the two Modules of planting. The silvicultural traita evaluated at 20 years were total plant height $(A L T, m)$, diameter at breast height $(\mathrm{DBH}, \mathrm{cm})$ and survival of planted individuals, which were used to calculate the variance component components of genetic parameters, using the genetic-statistical program SELEGEN-REML/BLUP. High genetic variability was observed among the genotypes for the silvicultural traits studied in the riparian reforestation. The accuracy was of high magnitude, showing good reliability of the results. The mixed model method (REML/BLUP) was adequate for the estimation of genetic parameters and prediction of genotypic values in riparian reforestation, and it could be used routinely.

\section{PARÂMETROS GENÉTICOS EM REFLORESTAMENTO CILIAR SEM ESTRUTURA DE PROGÊNIES POR MODELOS MISTO (REML/BLUP)}

RESUMO: O objetivo deste trabalho é estimar parâmetros genéticos para caracteres silviculturais em reflorestamento ciliar aos 20 anos de idade, sem estrutura de progênies por modelos mistos (REML/BLUP). O presente trabalho foi realizado na Fazenda de Ensino, Pesquisa e Extensão (FEPE) da Faculdade de Engenharia da Ilha Solteira, Universidade Estadual "Julio de Mesquita Filho" (FEIS/UNESP), localizada no município de Selvíria (MS). Em fevereiro e março de 1986 iniciou o plantio do reflorestamento ciliar em módulos, existindo dois modelos com diferentes números de espécies. $O$ espaçamento utilizado no plantio das espécies foi de $2 \times 3 \mathrm{~m}$. O reflorestamento ciliar tem uma área de 9,5 ha na soma total dos dois modelos de plantio. As características silviculturais avaliadas aos 20 anos foram a altura total de planta (ALT, m), o diâmetro na altura do peito (DAP, $\mathrm{cm}$ ) e a sobrevivência dos indivíduos plantados, as quais foram utilizadas para calcular as estimativas dos componentes de variância dos parâmetros genéticos, utilizando o programa genético-estatístico SELEGEN-REML/BLUP. Observouse alta variabilidade genética entre os genótipos para os caracteres silviculturais estudados no reflorestamento ciliar. A acurácia foi de alta magnitude, mostrando boa confiabilidade dos resultados. O método do modelo misto (REML/BLUP) mostrou-se adequado à estimação de parâmetros genéticos e predição de valores genotípicos no reflorestamento ciliar, podendo ser empregado rotineiramente. 


\section{INTRODUCTION}

Among the main consequences of deforestation are: depletion of timber stocks, accelerated soil destruction, gradual desertification, with consequent decrease in productivity, occurrence of floods and increase of the greenhouse effect. It is known that the forest is an association of living organisms in equilibrium, highly vulnerable to internal and external threats. Any damage can break the integrity of that harmonic cycle and cause chain destruction. Activities such as logging, farming, urban sprawl, fires and inadequate management of the soil, mining and even tourism and leisure, without appropriate criteria, can harm the forest.

The Cerrado stricto sensu is the biome that has been suffering the highest rates of deforestation due to the rapid process of expansion of the country's agricultural frontiers, attracting much of the national agribusiness to these areas. Among the vegetal formations of the Cerrado, the fluvial or riparian environment, it is characterized by being associated with water courses with high richness, genetic diversity and for its role in the protection of water resources, edaphic, wild and aquatic fauna. In this context, it is necessary to develop alternative models of management that will contribute to reduce the degradation process of riparian forests, such as restoring natural vegetation and preserving biodiversity, providing food and shelter to the local fauna, restoring the protection of body of water and avoid erosion.

The intense and disorderly devastation can lead to the disappearance of several forest species of ecological and commercial importance in several regions, with serious impairment of their genetic potential (KAGEYAMA; DIAS, 1982). Therefore, its restoration, using plant species suitable for this purpose, is an urgent and essential necessity for the conservation of the water resources of altered river basins (SALVADOR, 1989). The restoration or mixed planting of native species in deforested areas, aiming to form a forest as close as possible to the original one, has been the utopia of researchers who have been dedicating themselves to the recovery of areas of permanent degraded protection (KAGEYAMA; GANDARA, 2004). The genetic diversity promotes the raw material for the adaptation, evolution and survival of species and individuals, being fundamental for the sustainability and stability of the ecosystem (BARREIRA et al., 2006). That is, genetic variation is necessary for populations to be able to cope with environmental changes (SANTOS; DIAS, 20I3).

In the characterization of genetic diversity, basically four types of markers are used: morphological, biochemical, molecular and cytological (KAMADA et al.,
2009). Morphological markers have the advantage of being identified according to the commercial interest of the plant as: height $(\mathrm{H}), \mathrm{DBH}$ (diameter at breast height), wood density, stem shape, seed production, etc. Phenotypic traits are used as morphological markers since the time of Mendel as easily identifiable visual phenotypes.

According to Resende (2016) the procedure of estimation/prediction in the improvement of perennial species that is being most used is the REML/BLUP (restricted maximum likelihood/best non-vitiated linear prediction). The REML/BLUP method is an excellent genotypic evaluation procedure, and it is known as the mixed model methodology. This procedure naturally addresses the imbalance, leading to more accurate estimates and predictions of genetic parameters and values, respectively. In view of this situation, the present work aims to estimate genetic parameters for silvicultural traits in riparian reforestation at 20 years of age, without progeny structure by the mixed REML/BLUP models.

\section{MATERIAL AND METHODS}

The present work was carried out at the Fazenda de Ensino, Pesquisa e Extensão (FEPE) of the Faculty of Engineering of Ilha Solteira, Universidade Paulista "Julio de Mesquita Filho" (FEIS/UNESP), located in the municipality of Selvíria (MS).

The climate of the region was classified as Aw, according to the Köeppen system, presenting rainfall in the summer and dryness in the winter. By the current nomenclature at suborder level is a RED LATOSOL (EMBRAPA, 20I3). The study area is on the Paraná Sedimentary Basin Plateau, with very smooth slopes, flat and gently undulating relief (ALVES; SOUZA, 2008).

The riparian reforestation area is located at the FEPE and it was deforested and had an intense mechanized activity for rice planting (Silva et al 2016). In February and March of 1986 the riparian reforestation was carried out in two modules, with different numbers of species, using seedlings donated by CESP (Companhia Energética de São Paulo). The Module I (Table I) consists of 21 species, planted in 33 repetitions, and Module II (Table 2 ) by 14 species in 13 repetitions and the spacing used was the $2 \times 3 \mathrm{~m}$. The riparian reforestation has an area of 9.5 ha in the total sum of the two Modules of planting. In Table I and 2 are the sketch of species distribution of Module I and Module 2, respectively. The experiments have II planting lines, with the first and last rows ( $\mathrm{I}$ and $\mathrm{XI}$ ) being bordered. The identification of the species used in the riparian reforestation is presented in Table 3. The individuals originated from collections made in several trees and the seeds were mixed, that is, without control of progenies. 
TABLE I Schematic of distribution of Module I species from the riparian reforestation in FEPE.

\begin{tabular}{|c|c|c|c|c|c|c|c|c|c|c|c|c|c|c|c|c|c|c|c|c|c|}
\hline Line & \multicolumn{21}{|c|}{ Species } \\
\hline I & 10 & 12 & 2 & 17 & 21 & I & 4 & 18 & 13 & 14 & 11 & 19 & 5 & 6 & 9 & 3 & 16 & 15 & 7 & 20 & 8 \\
\hline II & 7 & 11 & 18 & 5 & 20 & 10 & 16 & 21 & 2 & 14 & 13 & 3 & 8 & 19 & 17 & I & 6 & 12 & 9 & 15 & 4 \\
\hline III & 10 & 6 & II & 12 & 18 & 2 & 5 & 20 & 15 & 14 & 8 & 21 & 17 & 7 & 4 & 3 & 19 & 9 & I & 13 & 16 \\
\hline IV & 17 & 15 & 7 & I & 6 & 14 & 5 & 13 & 2 & 18 & 8 & 3 & 16 & II & 10 & 9 & 20 & 4 & 21 & 12 & 19 \\
\hline V & 18 & 3 & 21 & 15 & 10 & 14 & 17 & 20 & 2 & 8 & 5 & 6 & 16 & 4 & 19 & 13 & 12 & 9 & I & 11 & 7 \\
\hline VI & 2 & 10 & 8 & 5 & 12 & 21 & 11 & 6 & 16 & 15 & 20 & 3 & 4 & 19 & 14 & 17 & 7 & 9 & 18 & 13 & I \\
\hline VII & 10 & 20 & 4 & 11 & 12 & 17 & 6 & 8 & 18 & 15 & 2 & 16 & 14 & 19 & 5 & 21 & 1 & 9 & 7 & 3 & 13 \\
\hline VII & 9 & 6 & 19 & 10 & 7 & 13 & 14 & 15 & 5 & 12 & 8 & 11 & 20 & 17 & 1 & 3 & 4 & 18 & 2 & 21 & 16 \\
\hline IX & 21 & 7 & 15 & 20 & 12 & 6 & 17 & 9 & 16 & 1 & 14 & 10 & 13 & 2 & 4 & 5 & 19 & 11 & 18 & 3 & 8 \\
\hline$X$ & 15 & 20 & 10 & 5 & I & 18 & 8 & 9 & 19 & 13 & 2 & 6 & 4 & 3 & 16 & 7 & 21 & 11 & 12 & 14 & 17 \\
\hline$X I$ & 9 & 16 & 5 & 11 & 15 & 18 & 21 & 12 & 17 & 10 & 8 & 2 & 4 & 14 & 6 & 13 & 3 & 20 & 1 & 7 & 19 \\
\hline
\end{tabular}

TABLE 2 Schematic of distribution of Module II species from the riparian reforestation in FEPE.

\begin{tabular}{ccccccccccccccc}
\hline Line & \multicolumn{11}{c}{ Species } \\
\hline I I & 14 & 9 & 4 & 3 & 6 & 1 & 5 & 13 & 2 & 12 & 10 & 7 & 8 & II \\
II & 9 & 11 & 8 & 2 & 12 & 7 & 10 & 4 & 1 & 13 & 6 & 14 & 3 & 5 \\
III & 9 & 11 & 7 & 12 & 4 & 3 & 8 & 6 & 10 & 14 & 13 & 5 & 1 & 2 \\
IV & 7 & 6 & 14 & 8 & 13 & 5 & 10 & 9 & 2 & 11 & 3 & 1 & 4 & 12 \\
V & 10 & 8 & 7 & 3 & 6 & 4 & 12 & 1 & 2 & 9 & 11 & 14 & 13 & 5 \\
VI & 11 & 8 & 2 & 6 & 9 & 10 & 12 & 7 & 4 & 13 & 3 & 1 & 14 & 5 \\
VII & 5 & 12 & 11 & 7 & 2 & 6 & 13 & 1 & 8 & 3 & 10 & 4 & 9 & 14 \\
VIII & 9 & 11 & 1 & 7 & 13 & 5 & 4 & 8 & 14 & 10 & 12 & 6 & 2 & 3 \\
IX & 1 & 14 & 5 & 11 & 7 & 9 & 6 & 4 & 3 & 8 & 12 & 10 & 13 & 2 \\
X & 9 & 3 & 7 & 14 & 12 & 1 & 2 & 8 & 6 & 13 & 4 & 10 & 5 & 11 \\
XI & 1 & 8 & 6 & 11 & 2 & 12 & 13 & 3 & 4 & 10 & 5 & 14 & 7 & 9 \\
\hline
\end{tabular}

The silvicultural traits evaluated at 20 years were: total plant height $(\mathrm{H}, \mathrm{m})$, diameter at breast height $(\mathrm{DBH}$, $\mathrm{cm})$ and survival (S) of planted individuals. The species Plinia trunciflora (I3A) and Alibertia edulis (I3B) did not enter the statistical analysis due the following fact: Due the insufficient number of seedlings of I $3 \mathrm{~B}$ to plant in both modules, some plots were planted with I3B and, then there are modules that were planted the two species, and these are not repeated equally in all modules. The silvicultural trait data were used to calculate the variance components using the genetic-statistical program SELEGEN-REML/BLUP (RESENDE, 2016), which uses genetic evaluation techniques involving the prediction of values and the estimation of variance components. The procedure adopted by the SELEGEN program to predict genetic values is BLUP (best univariate linear prediction), using estimates of variance components obtained by the maximum likelihood (REML) method.

The experiment was set up without a progeny structure and one site, each species was considered as a population and each module one replicate, so the SELEGEN-REML / BLUP was used, following the model 24 (RESENDE, 2006), which refers to complete blocks, several populations, without progeny structure, in one place: $y=X r+Z g+W p+e$, where $y$ is the data vector, $r$ is the vector of repetition effects (assumed to be fixed) plus the general mean, $g$ is the vector of genotypic effects of populations (assumed to be random ), $p$ is the vector of plot effects, $\mathrm{e}$ is the vector of errors or residuals (random). Capital letters represent the incidence matrixes for these effects.

The genetic parameters estimated by the silvicultural traits were: Vg: genotypic variance among populations; Vc: environmental variance between plots; Ve: residual variance; Vf: individual phenotypic variance; $h_{g}^{2}$ : individual heritability in the broad sense, that is, of the total genotypic effects of populations; $c_{p}^{2}$ : coefficient of determination of plot effects; $h_{m}^{2}$ : heritability of the population mean, assuming complete survival; accuracy of population selection, Ac: assuming complete survival; $m$ : Average of traits; LRT:I ikelihood ratio test; $C V r$ : coefficient of relative variation; $C V g$ : coefficient of genetic variation among progenies; CVe: coefficient of environment variation. Multivariate analysis was calculated using model I04 (RESENDE, 2006), which calculates measures of genotypic divergence based on the statistical distance of Mahalanobis. This distance allows to obtain alternative groupings, according to the Tocher method. The criterion for evaluating the Tocher grouping is that the mean of the genetic divergence measures within each group should be less than the mean distances between any groups. To obtain the Tocher grouping, the arboreal species $P$. trunciflora and $A$. edulis of Module $I$ and Eriobotrya japonica of Module II were withdrawn for the calculation, due to the presence of zeros values, which impaired statistical analysis.

\section{RESULTS AND DISCUSSION}

\section{Prediction of Genetic Parameters}

\section{MODULE I}

The $\mathrm{Vf}$ for the ALT trait was 27.4194 and the residual variance $(\mathrm{Ve})$ contributed $64 \%$. For $\mathrm{DBH}$, the residual variance ( $\mathrm{Ve}$ ) and genotypic variance among populations $(\mathrm{Vg})$ contributed similarly to the value of phenotypic variation (I44.0I). For the survival trait (S), 
TABLE 3 Species used in riparian reforestation at FEPE.

\begin{tabular}{|c|c|c|c|}
\hline Number & Name & Common name & Family/Subfamily \\
\hline \multicolumn{4}{|c|}{ Module I } \\
\hline I & Albizia lebbeck & Albizia & Mimosoideae \\
\hline 2 & Holocalyx balansae & Alecrim-do-campo & Caesalpinoideae \\
\hline 3 & Morus nigra & Amora & Moraceae \\
\hline 4 & Myroxylon peruiferum & Bálsamo & Papilionoideae \\
\hline 5 & Spondias lutea & Cajá-mirim & Anarcadiaceae \\
\hline 6 & Peltophorum dubium & Canafístula & Caesalpinioideae \\
\hline 7 & Ficus guaranitica & Figueira & Moraceae \\
\hline 8 & Psidium guajava & Goiaba & Myrtaceae \\
\hline 9 & Parapiptadenia rigida & Guarucaia & Mimosaceae \\
\hline 10 & Tabebuia sp. & Ipê-amarelo & Bignoniaceae \\
\hline II & Tabebuia roseo-alba & Ipê-branco & Bignoniaceae \\
\hline 12 & Tabebuia impetiginosa & a Ipê-roxo & Biognoniaceae \\
\hline $13 \mathrm{~A}$ & Plinia trunciflora & Jabuticaba & Myrtaceae \\
\hline I3B & Alibertia edulis & Marmelo & Myrtaceae \\
\hline 14 & Jacaranda cuspidifolia & Jacarandá-caroba & Bignoniaceae \\
\hline 15 & $\begin{array}{l}\text { Machaerium } \\
\text { acutifolium }\end{array}$ & $\begin{array}{l}\text { Jacarandá-do- } \\
\text { campo }\end{array}$ & Papilionoideae \\
\hline 16 & Syzygium cumini & Jambolão & Myrtaceae \\
\hline 17 & Licania tomentosa & Oiti & Chrysobalanaseae \\
\hline 18 & Ceiba speciosa & Paineira & Bombacaceae \\
\hline 19 & Koelreuteria paniculata & $a$ Quereutéria & Sapindaceae \\
\hline 20 & $\begin{array}{c}\text { Enterelobium } \\
\text { contortisiliquum }\end{array}$ & Tamboril & Mimosoideae \\
\hline 21 & Hovenia dulcis & Uva japonesa & Rhamnaceae \\
\hline \multicolumn{4}{|c|}{ Module II } \\
\hline I & $\begin{array}{c}\text { Anadenanthera } \\
\text { peregrina var. falcata }\end{array}$ & Angico-roxo & Mimosaceae \\
\hline 2 & urundeuva & Aroeira & Anacardiaceae \\
\hline 3 & Cordia ecalyculata & Café-de-bugre & Boraginaceae \\
\hline 4 & Mabea fistulifera & Canudo-de-pito & Euphorbiaceae \\
\hline 5 & Terminalia argentea & Capitão-do-campo & Combretaceae \\
\hline 6 & Genipa americana & Jenipapo & Rubiacea \\
\hline 7 & Inga sp. & & Mimosaceae \\
\hline 8 & Tabebuia sp & $\begin{array}{l}\text { campe-amarelo-do- } \\
\text { campo }\end{array}$ & Bignoniaceae \\
\hline 9 & Tabebuia heptaphylla & Ipê-rosa & Bignoniaceae \\
\hline 10 & Michelia champaca & Magnólia-amarela & Magnoliaceae \\
\hline II & Eriobotrya japonica & Nespereira & Rosaceae \\
\hline 12 & $\begin{array}{l}\text { Adenanthera } \\
\text { pavonina }\end{array}$ & Olho-de-dragão & Fabaceae \\
\hline $\begin{array}{l}13 \\
14\end{array}$ & $\begin{array}{c}\text { Leucana leucocephala } \\
\text { Melia azedarach }\end{array}$ & $\begin{array}{l}\text { Leucena } \\
\text { Santa-bárbara }\end{array}$ & $\begin{array}{c}\text { Mimosoideae } \\
\text { Meliaceae }\end{array}$ \\
\hline
\end{tabular}

the phenotypic variation (0.2285) had a greater contribution to the residual variation $(\mathrm{Ve}=0.1590)$ (Table 4).

The individual heritability in the broad sense $\left(h_{g}^{2}\right)$ was higher for the $\mathrm{DBH}$ trait. This result is expected since the $\mathrm{DBH}$ was the one that presented the greatest contribution of the genotypic variation among populations $(\mathrm{Vg})$ under the phenotypic variation $(V f)$. The coefficient of determination of plot effects $\left(c_{p}^{2}\right)$ was of low magnitude, indicating a low environmental variation. Values of observed in trials with high experimental control in perennial plants are around $10 \%$, when the estimated heritability is of the order of $30 \%$, that is, $10 \%$ of the total phenotypic variation within the block (FARIAS NETO et al., 2008). Thus, at the $30 \%$ level of individual heritability, $>0.10$ can be classified as low and $>0.10$ can be classified as high, thus allowing inference on spatial variability within blocks. The mean heritability of populations was high for all traits, suggesting high genetic progress in response to selection using population information.

The accuracy $(A c)$ was of high magnitude for the traits (0.99), according to Resende and Duarte (2007), showing robust reliability of the results, since the selective accuracy reflects the quality of the information and procedures used in the prediction of genetic values and the higher. The selective accuracy in the evaluation of a individual, the greater the confidence in the assessment and predicted for the individual. (PIMENTEL et al., 20I4). This measure is associated with the precision of selection and refers to the correlation between predicted genetic values and true genetic values of individuals.

The overall mean for the $H$ trait was higher in Module II, but lower for the $D B H$ and for the $S$ the Modules presented close values. The coefficient of genetic variation $(\mathrm{CVg})$, which indicates in percentage the general average of the amount of genetic variation (RESENDE, 2007) was superior for the DBH trait, but inferior to the experimental coefficient, similar to Canuto et al. (2016). The coefficient of relative variation $(\mathrm{CVr})$ and $\mathrm{CVg}$ indicated that $\mathrm{DBH}$ is the best trait for selection and the one that presents the best possibilities of finding superior progenies. Also, it is the trait with higher correlation with height (Table 5.) and second Silva et al. (20I2) is a trait easily measurable and that holds less percentage of error during its evaluation.

\section{MODULE II}

The genetic variance was the one of the variance componetes that contributed most to the phenotypic variance values for $H$ and $\mathrm{DBH}$ traits, reflecting the high individual hedge values in the restricted sense, a, 59 and 0.63 for $H$ and $D B H$, respectively (Table 4).

The coefficient of determination of plot effects $\left(c_{p}^{2}\right)$ indicated that there is a low environmental variation between plots, being higher for $\mathrm{S}$. The average heritability of populations was of high magnitude for the three traits evaluated, but it assumes complete survival, which does not occur in the experiment. Following the classification proposed by Resende and Duarte (2007), the accuracy was very high $(A c<0.90)$ for all evaluated traits.

The coefficient of genetic variation $(\mathrm{CVg})$ was highest for $\mathrm{DBH}$ and was also higher than the coefficient of experimental variation. The $\mathrm{CVr}$, which is the parameter 
TABLE 4 Estimates of genetic parameters for silvicultural traits studied from Modules I and II of riparian reforestation at 20 years of age.

\begin{tabular}{|c|c|c|c|c|c|c|}
\hline \multirow{2}{*}{ Parameter } & \multicolumn{3}{|c|}{ Module I } & \multicolumn{3}{|c|}{ Module II } \\
\hline & Height (m) & $\mathrm{DBH}(\mathrm{cm})$ & Survival & Height (m) & $\mathrm{DBH}(\mathrm{cm})$ & Survival \\
\hline $\mathrm{Vg}$ & 8.4400 & 67.6992 & 0.0408 & 26.1417 & 90.1113 & 0.0522 \\
\hline$V_{c}$ & I.35II & 6.2698 & 0.0287 & 0.1899 & 0.2974 & 0.0128 \\
\hline $\mathrm{Ve}$ & 17.6282 & 70.0440 & 0.1590 & 18.0535 & 52.5793 & 0.1677 \\
\hline$V f$ & 27.4194 & 144.0130 & 0.2285 & 44.3850 & |42.988| & 0.2328 \\
\hline$h_{\mathrm{g}}^{2}$ & $0.31 \pm 0.03$ & $0.47 \pm 0.04$ & $0.18 \pm 0.01$ & $0.59 \pm 0.09$ & $0.63 \pm 0.09$ & $0.22 \pm 0.03$ \\
\hline$c_{p}^{2}$ & 0.0493 & 0.0435 & 0.1256 & 0.0043 & 0.0021 & 0.0550 \\
\hline$h_{m}^{2}$ & 0.99 & 0.99 & 0.98 & 0.99 & 0.99 & 0.96 \\
\hline Ac & 0.9945 & 0.9970 & 0.9838 & 0.9971 & 0.9976 & 0.9789 \\
\hline $\mathrm{m}$ & 8.73 & 14.26 & 0.37 & 9.89 & 13.55 & 0.36 \\
\hline LRT & $311.99 * *$ & 517.15 *** & $383.93 * *$ & I87.23*** & $228.27 * *$ & $|37.3|$ |** \\
\hline $\mathrm{CVr}$ & 0.56 & 0.81 & 0.46 & 1.50 & I.54 & 1.04 \\
\hline $\mathrm{CVg}$ & 33.31 & 57.71 & 55.00 & 51.72 & 70.07 & 62.64 \\
\hline $\mathrm{CVe}$ & 59.70 & 71.21 & 119.30 & 34.40 & 45.36 & 60.55 \\
\hline
\end{tabular}

$* * \mathrm{P}<0.01$

that indicates the ratio between the genotype coefficient of the individual and the experimental coefficient was higher than one for all the traits, specialy for $\mathrm{DBH}$, which indicate the $\mathrm{DBH}$ as the most favorable trait for selection (ZARUMA et al., 20I5). Furthermore, the DBH is the trait that there is greater possibility of selecting better genotypes, indicated by the $C V g$, and has a high correlation with the ALT.

\section{Matrix of genetic correlation}

The genetic correlation between $\mathrm{H}$ and $\mathrm{DBH}$ was high and positive for both planting Modules (Table 5). Thus, trees with higher $\mathrm{H}$ also present greater $\mathrm{DBH}$ and the selection option based on $\mathrm{DBH}$ should be reflected in estimates of expressive genetic gains for both triats (SAMPAIO et al., 2002; SEBBENN et al., 2009). Survival showed a low genetic correlation with the other silvicultural traits studied, that is, it is more influenced by the environmental effect than the plant development.

TABLE 5 Genetic correlation between silvicultural traits for Module I and II of riparian reforestation at 20 years of age.

\begin{tabular}{ccccc}
\hline & \multicolumn{2}{c}{ Module I } & \multicolumn{2}{c}{ Module II } \\
\cline { 2 - 5 } & $\mathrm{DBH}$ & $\mathrm{S}$ & $\mathrm{DBH}$ & $\mathrm{S}$ \\
\hline $\mathrm{H}$ & $0.92^{* * *}$ & 0.49 & $0.94^{* *}$ & 0.44 \\
$\mathrm{DBH}$ & - & 0.36 & - & 0.34 \\
\hline
\end{tabular}

$* P<0.01$

\section{Mahalanobis Genetic Distances (Tocher)}

The formation of groups, by the Tocher method, made it possible to group the genotypes into five groups (Table 6). Group I contains $60 \%$ of the evaluated genotypes, showing similarities to the studied silvicultural traits, being far from groups 4 and 5 . In these two groups we have the arboreal species Ficus guaranitica (7) and Holocalyx balansae (2), species with larger and lower silvicultural performances in riparian reforestation at 20 years of planting (SILVA et al., 2007). It can be observed that in Module I there is high genetic variability for the silvicultural traits studied due to the number of groups formed that do not occurred for Module II of planting. In planting Model II the genotypes were grouped into one group (Table 6).

TABLE 6 Mahalanobis GENE Distinction (Tocher) Grouping for genotypes of the Module I and II.

\begin{tabular}{ccc}
\hline \multirow{2}{*}{ Group } & Module I & Module II \\
\cline { 2 - 3 } & Genotypes & Genotypes \\
\hline $\mathrm{I}$ & $3,4,5,6,8,10,1 \mathrm{I}, 12,14,16, \mathrm{I}, 2,3,4,5,6,7,8,9,10$, \\
$\mathrm{I}, 21$ & $13,14,12$ \\
2 & $\mathrm{I}, 15,17,19$ & - \\
3 & 9,20 & - \\
4 & 7 & - \\
5 & 2 & - \\
\hline
\end{tabular}

In general, there is a high genetic variability among the evaluated genotypes, as can be seen from the estimates of $\mathrm{CVg}$ and heritabilities. Thus, the modules of planting have a genetic variability and species diversity that may guarantees the survival and maintenance of the riparian reforestation. Riparian reforestation can be considered a germplasm bank with genetic diversity for seed production with quality and genetic variability. 


\section{CONCLUSIONS}

Genotypes of the species have high genetic variability for the silvicultural traits $\mathrm{H}$ and $\mathrm{DBH}$ at 20 years of planting.

There is a high positive genetic correlation between $\mathrm{DBH}$ and $\mathrm{H}$ traits, and the direct selection in one trait will results in indirect selection in the other.

The high accuracy of the genotypic values of the genotypes for the silvicultural traits studied indicate that the estimated parameters are robust.

The mixed model method (REML/BLUP) is adequate for the estimation of genetic parameters and prediction of genotypic values in riparian reforestation module trials.

\section{REFERENCES}

ALVES, M.C.; SOUZA, Z.M. Recuperação de área degradada por construção de hidroelétrica com adubação verde e corretivo. Revista Brasileira de Ciências do Solo, v. 32, p. 2505-25 I6, 2008.

BARREIRA, S.; SEBBENNA.M.; SCOLFORO; J.R.S; KAGEYAMA; P.Y. Diversidade genética e sistema de reprodução em população nativa de Eremanthus erythropappus (DC.) MacLeish sob exploração. Scientia Forestalis, n. 7I, p. II9-130, 2006.

CANUTO, D.S.O.; SILVA, A.M.; MORAES, M.L.T.; RESENDE, M.D.V. Estabilidade e adaptabilidade em testes de progênies de Myracrodruon urundeuva sob quatro sistemas de plantio. CERNE, v. 22, n. 2, p. I7I-I80, 2016.

EMPRESA BRASILEIRA DE PESQUISA AGROPECUÁRIA EMBRAPA. Sistema brasileiro de classificação de solos. 3.ed. Brasília, 2013. 353p.

FARIAS NETO, J.T.; RESENDE, M.D.V.; OLIVEIRA, M.S.P.; NOGUEIRA, O.L.; FALCÃO, P.N.B; SANTOS, N.S.A. Estimativas de parâmetros genéticos e ganhos de seleção em progênies de polinização aberta de açaizeiro. Revista Brasileira de Fruticultura, Jaboticabal - SP, v. 30, n. 4, p. I05I-I056, 2008

KAGEYAMA, P.Y.; DIAS, I.S. Aplicação da genética em espécies florestais nativas. Silvicultura em São Paulo, São Paulo, v. I6A, n.2, p.728-79I, 1982.

KAGEYAMA, P.Y.; GANDARA, F.B. Recuperação de áreas ciliares. In: RODRIGUES, R.R.; LEITÃO FILHO, H.F. (Ed.). Matas ciliares conservação e recuperação. 2.ed. São Paulo: Editora da Universidade de São Paulo, 2004. p. 249-269.

KAMADA, T.; PICOLI, E.A.T.; ALFENAS, A.C.; CRUZ, C.D.; VIEIRA, R.F;; OTONI, W.C. Diversidade genética de populações naturais de Diversidade genética de populações naturais de Pfaffia glomerata (Spreng.) Pedersen estimada por marcadores RAPD. Acta Scientiarum Agronomy. Maringá, v. 3I, n. 3, p. 403-409, 2009
PIMENTEL; A.J.B.; GUIMARÃES, J.F.R.; SOUZA, M.A.; RESENDE, M.D.V.; MOURA, L.M.; ROCHA, J.R.A.S.C.; RIBEIRO, G. Estimação de parâmetros genéticos e predição de valor genético aditivo de trigo utilizando modelos mistos. Pesquisa Agropecuária Brasileira, Brasília, v.49, n. I I, p.882-890, 2014

RESENDE, M. D. V. O Software Selegen-Reml/Blup. Documentos EMBRAPA, Campo Grande, 2006.

RESENDE, M. D. V. Software Selegen-REML/BLUP: a useful tool for plant breeding. Crop Breeding and Applied Biotechnology. Viçosa, v. 16, p. 330-339, 2016.

RESENDE, M.D.V.; DUARTE, J.B. Precisão e controle de qualidade em experimentos de avaliação de cultivares. Pesquisa Agropecuária Tropical. v. 37, n. 3, p. 182194, 2007.

SALVADOR, J.L.G. Considerações sobre as matas ciliares e a implantação de reflorestamentos mistos nas margens de rios e reservatórios. 2 ed. São Paulo: CESP/ ARI, 1989. 15p. (Série Divulgação e Informação, 105).

SAMPAIO, P.T.B; RESENDE, M.D.V.; ARAÚJO, A.J. Estimativas de parâmetros genéticos e métodos de seleção para o melhoramento genético de Pinus oocarpa Schied. Pesquisa Agropecuária Brasileira, Braílida, v. 37, n. 5, p. 625-636, 2002.

SANTOS, F.R.; DIAS, C.A.R. Fascículo - Evolução. Belo Horizonte: CAED-UFMG, 20I3. I52 p.

SANTOS, H.G.; JACMINE, P.K.T.; ANJOS, L.H.C.; OLIVEIRA, V.A.; OLIVEIRA, J.B.; COELHO, M.R.; LUMBRERAS, J.F.; CUNHA, T.J.F. Sistema brasileiro de classificação de solos. Rio de janeiro: Embrapa Solos, 2013. 353p.

SEBBENN, A.M.; FREITAS, M.L.M.; ZANATTOA.C.S.; MORAIS, E.; MORAES, M.A. Comportamento da variação genética entre e dentro de procedências e progênies de Gallesia integrifolia Vell. Moq. para caracteres quantitativos. Revista do Instituto Florestal, São Paulo, v. 2I, n. 2, p. I5I-163, 2009.

SILVA, A.M.; CANUTO, D.S.O.; CAMBUIM, J.; MORAES, M.L.T. Reflorestamento ciliar em diferentes modelos de plantio: margem do reservatório da hidroelétrica de Ilha Solteira. I9I p., I. Ed., Curitiba, 2016.

SILVA, J. M. AGUIAR, A. V.; MORI, E. S.; MORAES, M. L. T. Divergência genética entre progênies de Pinus caribaea var caribaea com base em caracteres quantitativos. Pesquisa Florestal Brasileira, Colombo, v. 32, n. 69, p. 69-77, 2012.

ZARUMA; D.U.G.; CANUTO; D.S.O.; PUPIN, S.; CAMBUIM; J.; SILVA; A.M.; MORI; E.S.; SEBBENN; A.M.; MORAES; M.L.T. Variabilidade genética em procedências e progênies de Dipteryx alata vogel para fins de conservação genética e produção de sementes. Scientia Forestalis, Piracicaba, v. 43 , n. 107, p. 609-6I5, 2015. 